\title{
FACTORS INFLUENCED PEOPLE IN CHOOSING UNIVERSITY: A LESSON FROM ISLAMIC ECONOMICS DEPARTMENT UII
}

\author{
Nur Kholis dan Meri Kartika \\ Dosen Prodi Ekonomi Islam FIAI UII, \\ Anggota Ikatan Ahli Ekonomi Islam (IAEI) dan BASYARNAS DIY \\ Email: nurkholisyes@gmail.com \\ Meri Kartika, SEI \\ Prodi Ekonomi Islam FIAI UII
}

\begin{abstract}
Abstrak
Praktik ekonomi Islam di Indonesia yang semakin meluas menimbulkan tantangan baru berupa penyediaan Sumber Daya Manusia (SDM) yang kompeten. Ikhtiar menjawab hal tersebut, di antaranya pendirian lembaga pendidikan ekonomi Islam. Dalam konteks itu, Universitas Islam Indonesia mendirikan prodi Ekonomi Islam tahun 2003. Prodi ini mengalami trend penurunan minat calon mahasiswa pada awal berdiri hingga 2006, terus berbalik mengalami kenaikan peminat yang sangat signifikan sejak 2007 hingga 2014. Kenaikan signifikan tersebut menarik untuk diteliti, apa faktor penentu kenaikannya. Tujuan penelitian ini untuk menganalisis faktor apa saja yang mempengaruhi calon mahasiswa memilih kuliah di Prodi ekonomi Islam FIAI UII tahun 2011-2014. Hasil penelitian secara parsial menunjukkan bahwa variable variable biaya pendidikan 25.41390, variable fasilitas pendidikan 24.48315 , variable citra kampus dan nama besar UII 14.28829, variable peluang kerja 22.21724, variable dorongan orang tua dan informasi dari brosur 26.81530, berpengaruh secara signifikan terhadap minat mahasiswa memilih jurusan ekonomi Islam FIAI UII. Sedangkan secara simultan, disimpulkan 98\% mahasiswa memilih kuliah di Prodi Ekonomi Islam dipengaruhi oleh variable-variable di atas dan 2\% lainya dipengaruhi oleh variable yang tidak diteliti dalam penelitian ini.
\end{abstract}




\section{تجريد}

إن عملية التنفيذ الاقتصادية الإسلامية في إندونيسيا الواسعة الانتشار تؤدي إلى ظهور تحديات جديدة كتوفير الموارد البشرية (SDM) المختصة. فمن الردود على

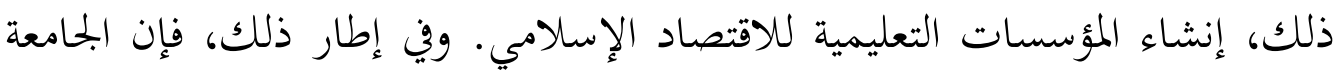

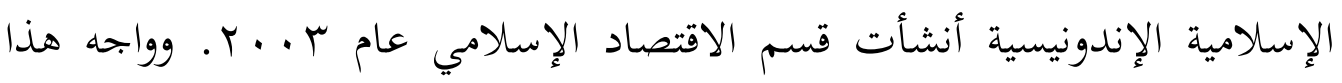

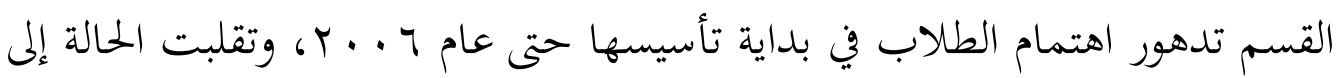

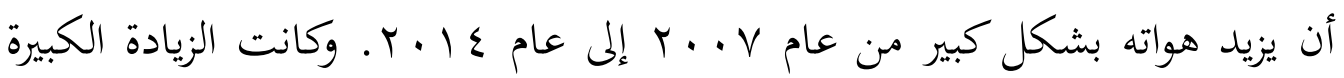

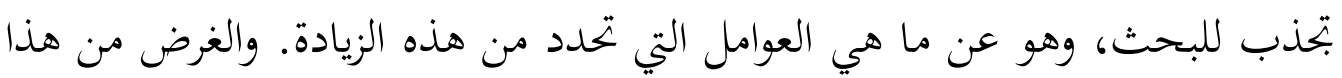
البحث هو تحليل العوامل التي تؤثر بالطلاب المرشحين على الختيار الدراسة في قسم

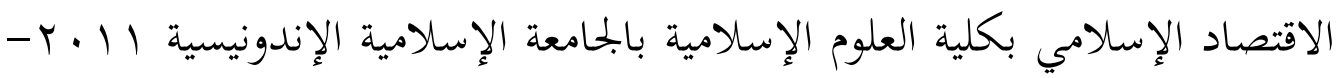

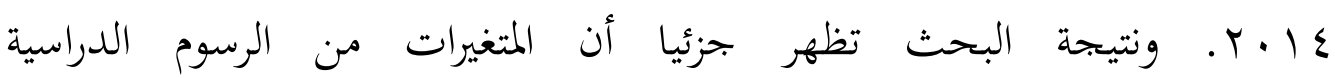
. الشهير MNAYq

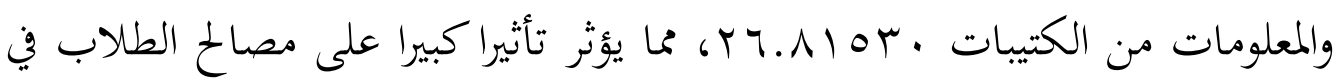
اختيار قسم الاقتصاد الإسلامي بكلية العلوم الإسلامية بالجامعة الإسلامية

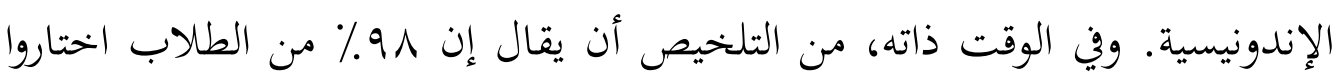
قسم الاقتصاد الإسلامي بسبب تأثيرات المتغيرات السابقة و ؟٪ من المتغيرات التي لم

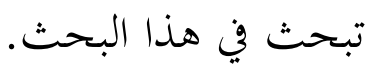

Keywords: Islamic Economics Department, Factors influenced, Human resources. 


\section{A. Introduction}

The Development of Islamic economic practice in Indonesia has been very significant growth for the last twenty years. The development is not limited to the practice in the field of Islamic banking and Islamic insurance, but expanded into all aspects of the financial sector and the real sector. The financial sector covered Islamic capital market, Islamic mutual funds, Islamic leasing, Islamic mortgage, Islamic trade finance, sukuk (Islamic bonds), and others. The real sector covered Sharia hotel, Islamic culinary, Islamic fashion, Islamic tourism and others. ${ }^{1}$ In other words, all industries that can be done by Islamic lawfull, the products of Islamic economics were be there.

The development of Islamic economic practices that really preeminent can be seen from the Islamic banking and financial sector. Until October 2014, the sum of Islamic banking network office reached 2950 offices. The Islamic banking industry is composed of 12 Islamic Banks (BUS) with 2,157 offices, 22 Sharia Business Unit (UUS) with 362 offices and 163 BPRS with 431 offices. Total assets of the Islamic banking in October 2014 reached Rp 260.366 trillion. Islamic banking industry is able to demonstrate high growth performance to an average of $40.2 \%$ per year in the last five years, while the average growth of the national banking system amounted to only $16.7 \%$ per year. Therefore, the Islamic banking industry was dubbed as 'the fastest growing industry'. ${ }^{2}$

This rapid growth of this industry is supported by the broad of potential economic market. Indonesia is a country with a population of approximately 260 million peopple, $87.18 \%$ of them are Muslims. ${ }^{3}$ It became the largest Muslim country in the world. It is an enormous market for the development of Islamic economic practice in its various aspects. Islamic economic practices in both of the financial sector and the real sector continue to grow. This fact emerged new challenges and opportunities for providing a capable human resources in the field of Islamic economics. This encourages the development of Islamic

1 Nur Kholis, "Potret Politik Ekonomi Islam di Indonesia Era Reformasi", Jurnal MILLAH, Magister Studi Islam UII (accredited), Vol. X, No. 2, February 2011, p. 420-421.

2 OJK, Statistik Perbankan Syariah, Oktober 2014. Publication can be downloaded at website OJK (Otoritas Jasa Keuangan), http:/ / www.ojk.go.id/

3 http://www.republikapenerbit.com/artikel/detail_info/292, accessed December, 12 2014 
economics education at various levels, from the high school level to college, starting from S1 (undergraduate program), S2 (master), until S3 (doctoral).

The rapid development of Islamic finance and banking industry demanded human resources that having a good qualification in the field of Islamic economics. One of the problems that faced by the Islamic finance industry in Indonesia is the availability of qualified human resources. The continued development of Islamic banking and finance industry encourage the increasing need for qualified human resources. Bank Indonesia (BI) has stated to pursue Islamic banking market share to five percent, this target strive for the availability of about 40 thousand qualified human resources. ${ }^{4}$ The second problem is the lack of public awareness to Islamic finance and banking system. It is seen from the lowest number of Indonesian moslem who accessed the services of Islamic banking than conventional banking services.

One of the world's largest management consulting firm, AT Kearney reported that lack of qualified human resources in Islamic banking sector will be the biggest obstacle in developing the industry. Moreover, with the continued development of the Islamic banking industry, the demand for newly qualified human resources will be greater in the future. AT Kearney predicts that Islamic banking industry in the Middle East requires at least 30 thousand of new qualified human resources in the next decade (10 years into the future, namely 2017).

According to the Director of Dow Jones Islamic Market Index (DJIM), Rushi Siddiqui, limited also occur on the side of the sharia supervisory. Moreover, the need for human resources in sharia supervisory is predicted to increase in line with the increasing number of conventional financial institutions began to adopt Islamic business. Siddiqui said that the latest data from Islamic Finance Information Service (IFIS) in London shows the number of international Islamic scholars were very limited currently. One expert on Sharia supervisory, Sheikh Muhammad Taqi Usmani, believes that the development of Islamic financial institutions should also involve the development of human resources quality. It is also associated with the understanding of modern financial transactions and its relation to sharia law.

\footnotetext{
4 Republika, May, 22007
} 
Thus, opportunities to fulfill the needs of thousands human resources in Islamic economic expertise are opened widely. For this reason, many education and training institutions compete to provide many programs to meet the opportunities. Among the training institutions, they are; Tazkia Institute, Shariah Economic and Banking Institute (SEBI), the Center for Training and Development Resources Mandiri (PPSDM), Muamalat Institute, Karim Bussiness Consulting and Sharia Banking Division of the Indonesian Bankers Institute (IBI), etc. Among formal educations, they are; Islamic Economic Department Faculty of Islamic Studies Islamic University of Indonesia (FIAI UII), SBI institute, SEBI, STEI Yogyakarta, Department of Islamic Economics STAIN Surakarta, Faculty of Economics and Bussines at several UINs in Indonesia, severeal IAINs Indonesia, Faculty of Economics Airlangga University, STEI Tazkia, and the Department of Middle East and Islamic UI, Trisakti and others. ${ }^{5}$

Although the existence of Islamic economic in Indonesia is relatively new, but it has encourage many institutions to open courses in Islamic economics. According to data of Sharing magazine, April 2009, there are 52 universities that teach Islamic economics under the Ministry of Religious Affairs and the Ministry of Education. They provide courses in many level, namely diploma, undergraduate, graduate to doctorate. ${ }^{6}$ This situation drives all providers to compete each other.

Islamic Economics Department Faculty of Islamic Studies Islamic University of Indonesia operated on 2003. Since it opened, it has a dynamic development. When it opened in 2003, It has 37 new students, but it decreased until 2006, the number of new students is only 15 people, one of them retreated, so only 14 new students left. After that period, it began 2008 onwards until 2014, the number of applicants and the number of new students in Islamic Economics Department Faculty of Islamic Studies Islamic University of Indonesia was increased significance.

The above phenomena is interesting and important to investigate, because it is not easy for a student to decide what university and department that

5 Nur Kholis, "Prospek Pendidikan Ekonomi Islam Dalam Konteks Trend Ekonomi Global", A Paper was presented in SIMPONAS Ekonomi Islam ke-4 at Hotel Sahid Raya Yogyakarta, October, 8-9 2009.

6 Indah Piliyanti, "Perspektif Mahasiswa (Sebuah Kajian Pemasaran Pendidikan)", Tesis, Magister Studi Islam, Universitas Islam Indonesia, p. 2 
he or she will take as a vehicle to pursue his or her aspiration. This decision determines his or her future. If he or she make a wrong decision, he or she will get complication very much, he or she will drop-outs or will fail to complete the study. Conversely if he or she make a right decision in choosing university and department that suitable with his or her aspiration, he or she will get a brght and clear future. ${ }^{7}$

In the case of Islamic economic department FIAI UII, there are several variables considered as factors influenced people in choosing Islamic economic department (a department in Faculty of Islamic Studies Islamic University of Indonesia). They are the cost of education, educational facilities, campus image and brand of UII, job opportunities, the encouragement of family and information from brochures. The research observes for a duration of time from 2011 to 2014. Hopefully the result of this research will be taken by the Chief of Islamic Economics department as a consideration for decising marketing strategy and management strategy to increase student satisfaction and to increase the the number of new students.

The purpose of this study was to analyze the effect of the cost of education, educational facilities, campus image and brand of UII, job opportunities, and the encouragement of family and information from brochures in student's decision to choose the university, especially when they choose Islamic Economics department Islamic University of Indonesia. This research was a field research, and a quantitative descriptive based. This research uses multiple linear regression analysis and adopts the program E-views for data processing.

\section{B. Islamic economics department Faculty of Islamic Studies UII}

Islamic economics department Faculty of Islamic Studies Islamic University of Indonesia (FIAI UII) was established in 2003 by decree of the Directorate General of Islamic Higher education Ministry of Religious Affairs No. DJ / $178 / 03$. This department was opened as a form of response to public demand for providing an education program thaught Islamic economic in university. For this reason, in order to implement the vision of UII, namely to be qualified as a

7 http://edukasi.kompasiana.com/2013/02/22/telusuri-bakat-minat-dan-kemampuan535944.html accessed 12/11/2013 
university in developed countries, Islamic Economic Department was opened in Faculty of Islamic Studies Islamic University of Indonesia since academic year 2003/2004.

The existence of Islamic Economic Department Faculty of Islamic Studies, Islamic University of Indonesia was a response to the demands of the times in the future that is characterized by technological progress fastly and high levels of turbulence changes in the economic environment, social, cultural, and political. This condition requires the readiness of qualified human resources. Such human resources are characterized by the ability of reliable analysis and prediction, having a comprehensive theoretical science and accompanied with high moral integrity. UII experienced more than 70 years in providing qualified education program, Islamic economics department would be part of qualified education program in UII.

According to the General Directorate of Islamic Higher Education at the time (Prof. Dr. Arif Furqan), Islamic Economics department FIAI UII is the first education program that obtained an operating permit from the Ministry of Religious Affairs to issue a degree in Islamic Economics (SEI). For this reason, because of the absent of islamic economic curriculum in Ministry of Religious Affairs at the time, before operating permit granted, the General Directorate of Islamic Higher Education asked UII to conduct a curriculum workshop for designing Islamic economics curriculum. The result of the workshop will be a guideline for other campusses that provided Islamic economics program in their education program.

In the journey to reach the vision and mission, Islamic Economics department FIAI UII experienced a decreasing condition and increasing condition. This course has ups and downs. Opened at the beginning of 2003, the public response is good enough, it is evidenced by the number of new student registrated that reached 37 students. But in the following year, there was a downward trend until 2006. Even in the academic year 2006, only 15 new students registered, unfortunately one of them retreated, it means only 14 new students left. After 2007, Islamic Economics department FIAI UII goes to have positive trend, namely the number of new students increased, the number of applicants also increased. This shows that more and more people who appointed his choice to join Islamic Economics department FIAI UII. This is illustrated by the following chart. 
Graph 1. The applicant and registrant in Islamic economics department FIAI UII

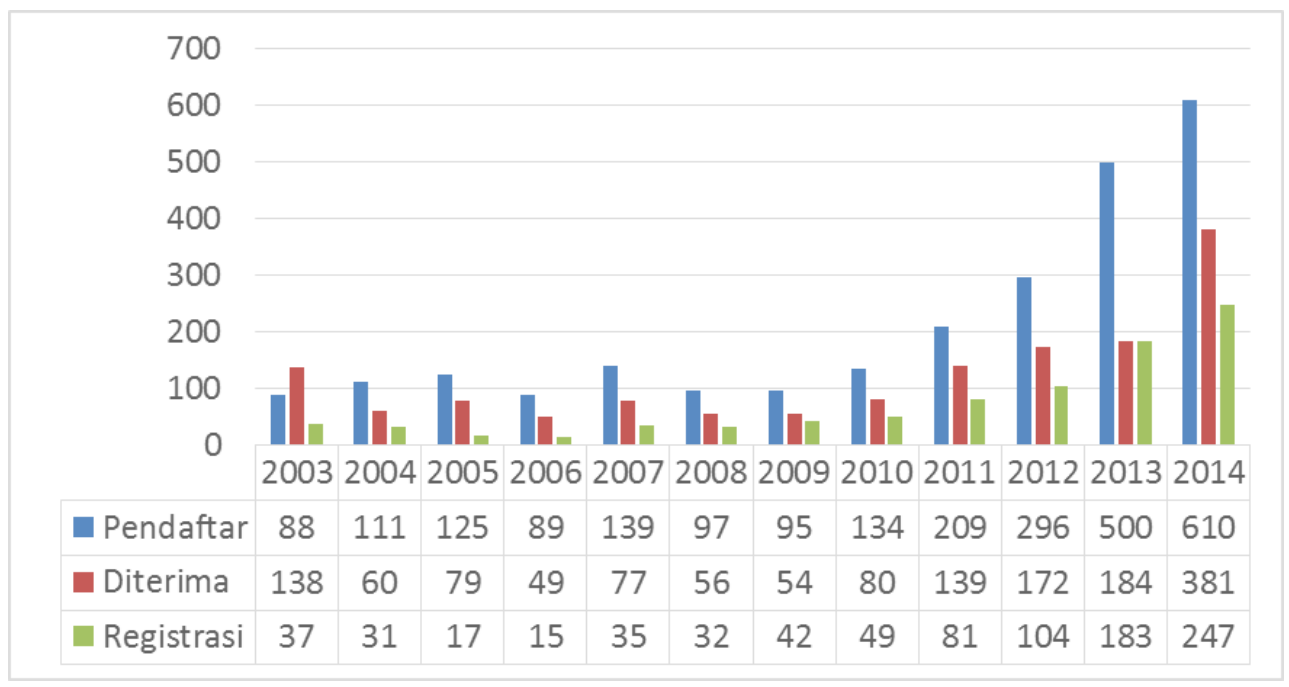

Source: A Document from Islamic Economics department

The vision of Islamic Economics department FIAI UII is to be a leading institution in providing competence and intelectual human resources theoretically and practically in the field of Islamic economics and characterized as rahmatan lil Alamin. The mission of Islamic Economics department FIAI UII are described below:

1. Being a center of education, study, research and development and dissemination of Islamic economics.

2. Provide graduates who have the skills in the field of economics and finance theoretically and practically based on Islamic character, Professional, Istiqomah and Communicative (APIK).

3. Provide graduates who have professionalism and expertise in Islamic economics that have excellence commitment in developing extraordinary knowledge and IT.

4. Build and develop a good synergy with the Islamic financial institutions to develop and communicate Islamic economics through education, research, community service and preaching Islamiyah.

Islamic Economics department FIAI UII has the competitive advantages as follow: 
1. Islamic Economics department FIAI UII is the first institution awarded operational permit legally from DIKTIS Kemenag RI as an institution that has an authority to produce human resources in the field of Islamic economics with a title SEI (Sarjana Ekonomi Islam).

2. In the beginning period of acreditation BAN-PT, Islamic Economics department FIAI UII awarded Grade B.

3. Islamic Economics department FIAI UII is a part of the Islamic University of Indonesia, the oldest university in Indonesia that has been experienced in managing higher education more than 71 years. Institution accreditation of UII is A.

4. Islamic Economics department FIAI UII has a set of curriculum that balanced between economics and finance and muamalah as acknowledgement from many expert in Islamic economics. The curriculum was resulted from several process and benchmarked to the curriculum of Al-Azhar University in Cairo, International Islamic University Malaysia, International Islamic University Islamabad Pakistan, and the University of Malaya in Malaysia. The curriculum has been adopted by many universities in Indonesia as well as state university and private university.

5. Islamic Economics department FIAI UII has experienced lecturers and some lecturers from abroad, especially in the study of Arabic language.

6. Islamic Economics department FIAI UII organizes internships in islamic Financial Institutions and Islamic Business institution as an instrument to introduce students to the riel work of islamic Financial Institutions and Islamic Business institution. ${ }^{8}$

\section{Factors Affecting College Options}

Factors that influenced students in choosing university are very diverse. In this research, researcher determined five factors that influenced them in choosing university, namely educational cost, educational facilities, campus image and brand name of UII, job opportunities, and the encouragement of

\footnotetext{
8 Brosur FIAI UII
} 
family and brochure information. These factors were treated as independent variables $(\mathrm{X})$.

The dependent variable is influenced by variations of variable independent or variable criteria. The change of dependent variable is determined by the variations in the free variable changes. ${ }^{9}$ Dependent variable was applied in this research is student decision in choosing Islamic economic department FIAI UII as their place of study.

Independent variable is a variable that influenced the change of dependent variable. It was used as predictor variable. ${ }^{10}$ There are five independent variables examined in this research, namely:

1. Educational Cost (X1)

2. Educational Facilities Fasilitas pendidikan (X2)

3. Campus image and brand name of UII (X3)

4. Job opportunities (X4)

5. The encouragement of family and brochure information (X5)

\section{Characteristics of Respondents}

1. Number of Respondents

The number of respondents who becomes the object of this research amounted to 170 people, consisting of 30 students from the academic year 2011, 40 students from the academic year 2012, 50 students from the academic year 2013, and 50 students from academic year 2014. Here the researchers explained in a diagram drawing.

9 Sulisyanto, Metode Riset Bisnis, (Yogyakarta: Andi Offset, 2009), p. 78

10 Ibid., p. 78 
Figure 5.1

Number of Respondents

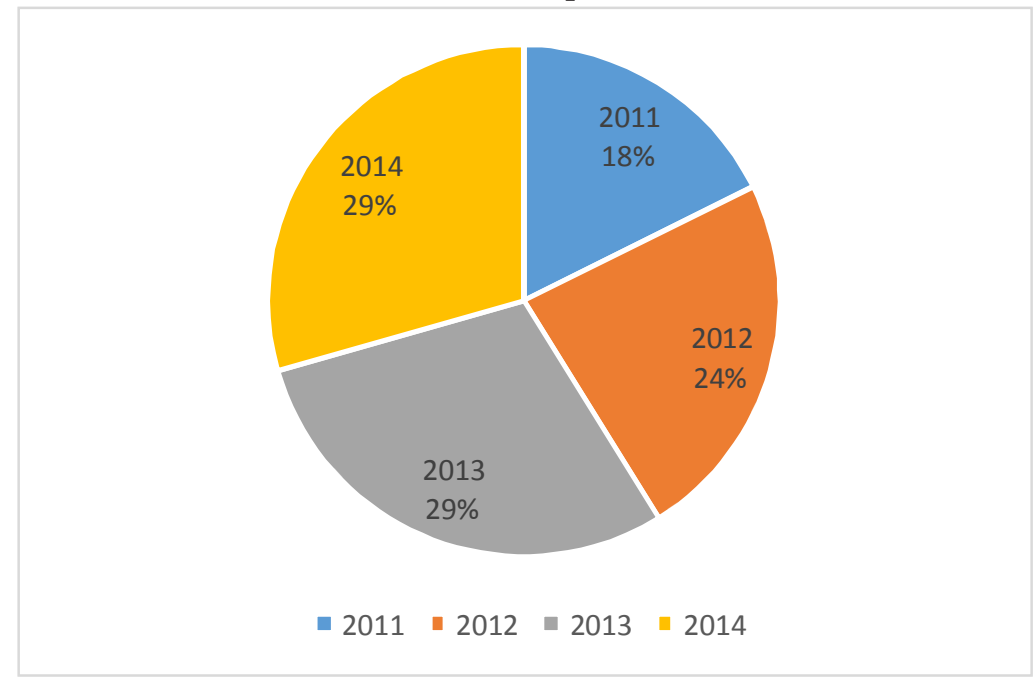

Source: Primary data that have been processed, 2014

2. Number of Respondents According to Gender

Based on the data obtained from the questionnaires, the number of female respondents is 87 people and the number of male respondents is 83 . The following is a figure about it.

Figure 5.2

Number of Respondents Based on Gender

\section{Gender Classification of Respondent}

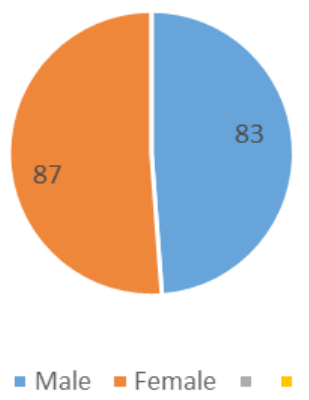

Source: Primary data that have been processed, 2014 
3. Number of Respondents According to Choice Priority

Based on the data obtained from the questionnaires of this research, how many respondents choosed UII as the first choice in study can be explained. 107 respondents of 170 respondents choosed UII as the alternative choice in their study, and the rest, namely 63, they choosed UII as the first choice in their study. The following is a figure explained about it.

Figure 5.3

Number of Respondents According to Choice Priority

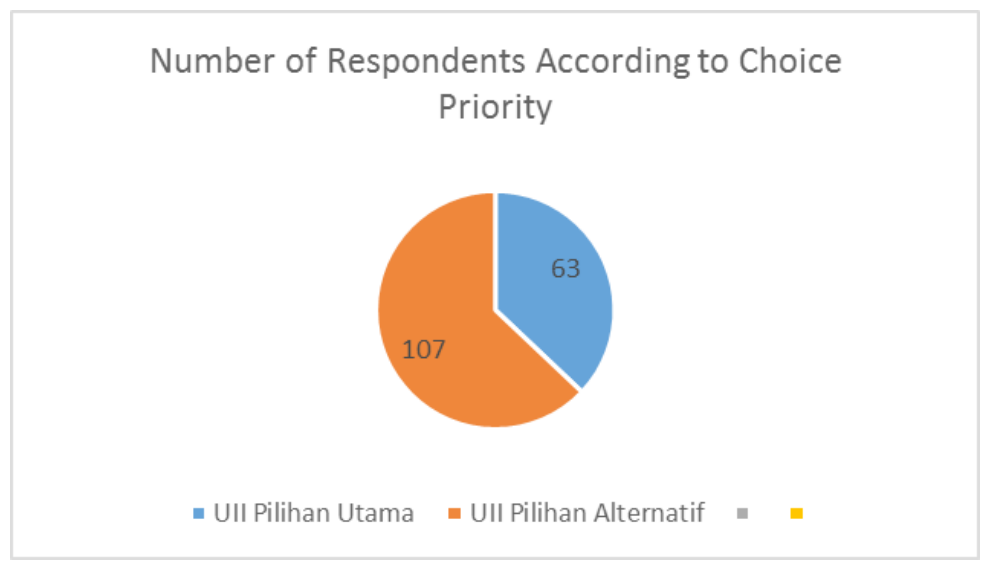

Source: Primary data that have been processed, 2014

The reasons of respondents to decide Universitas Islam Indonesia as the alternative chioce are many, namely: respondents desire to continou their study to state university (Perguruan Tinggi Negeri - PTN), a minimum information about the quality of Universitas Islam Indonesia, and the image about the cost, that the cost in private university more expensive than state university. Although it is not always correct.

Based on data obtained from the the questionnaires of this research, it can be explained that 93 respondents of 170 respondents choosed Islamic economics Department FIAI UII as the first chioce, 57 respondents of 170 respondents choosed other departments in UII as the first choice and choosed Islamic economic Department as the alternative choice, 20 respondents of 170 respondents answered uncertain or halfhearted. The following is a figure explained about it. 
Figure 5.4

Respondents According to Department Priority Choice

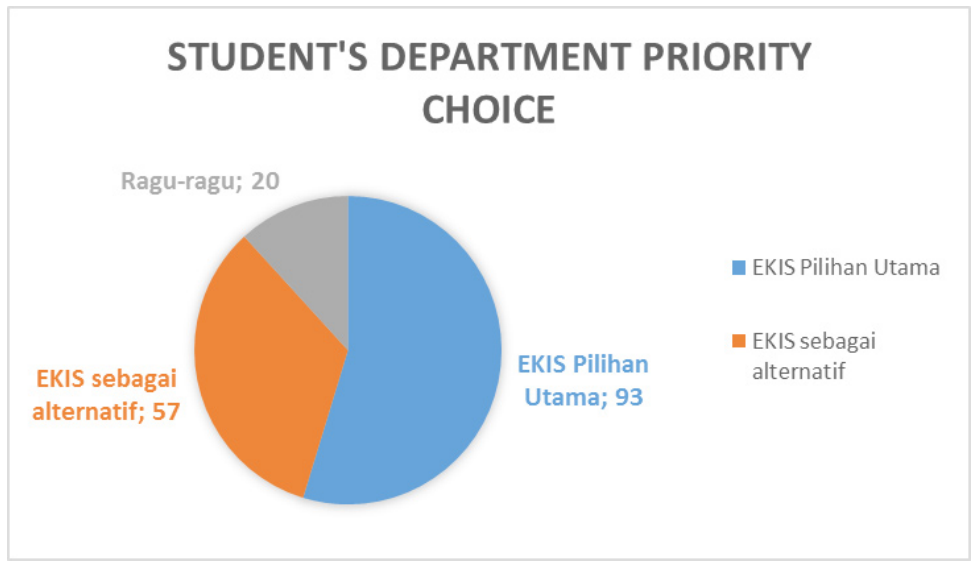

Source: Primary data that have been processed, 2014

4. Number of Respondents According to Information Media Type Information about Islamic economics Department can be obtained from many types of media. Many types of information media provided bay university made respondent easy to get any information about the departments existing in Universitas Islam Indonesia. Based on data obtained from the the questionnaires of this research, it can be explained that $25 \%$ of respondents got information from family, relatives, and alumni, $15 \%$ from the brochure, 10\% from pamflet and magazine, $22 \%$ from friends, $18 \%$ from university website, 5\% from faculty website, and $5 \%$ from teacher recommendation in senior high school.

\section{E. An Analysis of Students' Determinants to Study in Islamic Eco- nomics Study Program, Faculty of Islamic Studies, Islamic Univer- sity of Indonesia}

The development of Islamic economics practices, especially in finance and banking, either in the world or in Indonesia is delightful. Both financial services and Sharia banking exist in many countries. Nowadays, there are not less than 75 countries have practiced economics systems and Islamic finance, including in Asia, Europe, America, and Australia. 
Similarly in the academic field, several leading universities are actively developing an academic study about Islamic economics. Harvard University is one of the universities, which develops the study. Six British universities are involved in developing Sharia economics studies. Mettwally in Australia as well as Volker Nienhaus in Europe also evolve the study. Islamic economics scientists are not only Muslims, but they are also non-Muslims.

The growth and development of several universities opening Islamic Economics study programs promote the competition among the universities to provide the best quality in education. Prospective students will consider a quality university as their place to study. This research, as explained in the previous chapter, identified five determinants that influenced the prospective students' choice to study in Islamic Economics study program, Islamic University of Indonesia. Those five factors were the tuition fee, educational facilities, campus image and popularity of the university, employment opportunities, family support and information from the brochure. The results of the five determinants are described as follows.

\section{The affordable tuition fee}

The tuition fee assigned by the study program had a significant influence towards the students' interest in choosing Islamic Economics study program, at significance level of 5\% in this research. From the coefficient regression value employed by E-views, the tuition fee was 25.41390. It shows that if the tuition fee was revised one unit, the students' interest in selecting out the study program would increase by 25.41390 units.

Therefore, the more the tuition fee is affordable, the more the students are interested in studying in Islamic Economics study program, Islamic University of Indonesia. It can be suggested that the affordable tuition fee takes positive effect towards the students' interest in the study program.

This possibility occurred since the tuition fee assigned by the study program was cheaper than tuition fees in other study programs. Recently, the study program is not necessary to raise the fee, so the prospective students will remain to choose the program. Yet, the study program needs to adjust trends in rising tuition fee in the other study program in Islamic University of Indonesia, or in other universities. 


\section{The adequate education facilities}

In this research, the education facilities provided by a university had positive influences towards the students' interest in choosing the study program. At significance level of 5\%, the facilities in Islamic Economics study program had a value of 24.48315 , which means that if there was an improvement in the facilities conducted by the study program, the change would be at 24.48315 towards the students' interest in choosing the study program.

It can be concluded that the more complete and better the facilities are provided by the study program, the more positive the students are interested in the program. Conversely, if the availability of the facilities decreases, the students' interest will also be low.

The facilities in the study program are provided by Yayasan Badan Wakaf Islamic University of Indonesia via Kantor Pengelola Kampus (KPK), including the lecture halls, computer laboratory, Sharia mini banking laboratories, library, office, student activity facilities, and parking lot. It also provides supporting facilities which are electricity, water, and telephone. The principle implemented to utilize the facilities in the surroundings of integrated campus of Islamic University of Indonesia is sharing facilities, aiming at optimizing the utilization of the facilities efficiency.

Islamic Economics study program, Faculty of Islamic Studies, Islamic University of Indonesia is located in the integrated campus of Islamic University of Indonesia, Kaliurang street, KM. 14,5, Yogyakarta. There are two study programs of the Faculty of Islamic Studies, namely Islamic Law and Islamic Education, accredited A by BAN-PT. The fourth-floor building where the faculty sited belongs to Yayasan Badan Wakaf, Islamic University of Indonesia. According to the university's policy, Faculty of Islamic Studies shares the facilities with Faculty of Industrial Technology.

The main learning supporting facilities are projectors, computers in the classroom, Wi-fi, whiteboards, blackboards, sound systems, board markers, laboratory equipments, and books in the library. Even though the facilities are ready to use, but those are still inadequate. The Wi-fi network often has problems, and it cannot be accessed in the classrooms. There are three laboratories, namely laboratory of mini banking, computer laboratory, and laboratory of Galeri Investasi Syariah (GIS). There is an opportunity to improve the facilities 
in the future to attract the public interest to study in Islamic Economics study program, Islamic University of Indonesia.

The facilities become one of the attractiveness for the students who have chosen the study program. Yet, basically, the adequate building and the classrooms should be balanced by the adequate lecturers, so the successful teaching-learning process can be conducted. The ratio of the lectures to students should be adapted, and the quality of the lectures has to be improved.

\section{The influences of campus image and the popularity of Islamic University of Indonesia}

The image and popularity of Islamic University of Indonesia involve Islamic nuance in the campus life. Moreover, the accreditation of Islamic University of Indonesia also had a significant influence towards the students' interest. The image and popularity of the university at significance level of $5 \%$ had a coefficient regression of 14.28829. If there was an increase of one unit in these factors, the students' interest would be at 14.28829.

Therefore, the better and greater the image of Islamic University of Indonesia brings positive impact towards the students' interest in selecting out the study program. On the contrary, if the image and popularity of the university decline, there will be negative impact on the students' interest.

Recently, the image and popularity of the campus has increased. For example, first, Islamic University of Indonesia is accredited in A category. Second, many study programs in the university has received A accreditation. Third, the university guarantees the quality in the national top 10. Fourth, the achievements of the students and lectures have been increasing. It is important to improve the image and popularity of Islamic University of Indonesia to attract the prospective students to study in the study program.

\section{The significant influence of employment opportunities}

Employment opportunities had positive influence towards the students' interest in determining the study program they were going to take. The high employment opportunities in the Sharia financial sector contributed the regression coefficient value of 22.21724 of a $5 \%$ significance level. It can 
be interpreted that if there was an increase of one unit of the employment opportunities, the students' interest would rise by 22.21724 units.

The increase of the students' interest in choosing the study program can possibly happen since Islamic economic systems have been increasingly recognized. In addition, because the majority of population in Indonesia is Muslims, many financial institutions, either bank or non-bank, set up Shariabased financial institutions. Predicted by Pengawas Bank Madya Senior Bank Indonesia Surabaya, Bambang W. Budiman, Sharia Bank will require about 9,000 employees until 2014.

It proves that the greater employment opportunities will bring positive effects towards the students' interest in studying at Islamic Economic study program of Islamic University of Indonesia. If the employment opportunities decline, the students' interest will obviously be low. It means that the variable of employment opportunities have reasonable influences towards the students' interest in choosing the study program.

The employment opportunities is supported and formed by the growing volume of Islamic economic practices. Within the last two decades, the development of Islamic economics practices has evolved significantly. This is not only limited to banking and Sharia insurance, but this also affects either financial or real sectors. In the financial sectors, the practices of Islamic economics has got in on Sharia capital markets, Sharia Reksadana, Sharia leasing, Sharia pawnshop, Sharia export financing, Sharia obligations (Sukuk), and others. In the real sectors, there are the development of Sharia hotels, Sharia culinary, Sharia clothing, and Sharia tourism ${ }^{11}$. In other words, Sharia economics products have successfully penetrated many halal industries. Those real indicators encourage the increase in employment opportunities in Islamic economics sectors in the future.

\section{The significant influences of the parents' encouragement and informa- tion from the brochures.}

This research demonstrated the significant influences both the parents' encouragement and the content of the brochures. At a 5\% significance level, a

11 Nur Kholis, "Potret Politik Ekonomi Islam di Indonesia Era Reformasi", in Jurnal MILLAH, Magister Studi Islam UII (accredited), Vol. X, No. 2, February 2011, p. 420-421. 
coefficient of the encouragement and the brochures was 26.81530. This indicated that if the encouragements and the brochures increased by one unit, the students' interest in choosing the study program would raise 26.81530 units.

Therefore, the greater the encouragement and the more complete the information in the brochures, the greater the students are interested in choosing the Islamic Economics study program.

Even though the parents allow the students to decide where they are going to study, the parents' encouragement is notable for guiding the students to determine the program. The development of technology and communication enable the parents and their children to search for any information related to colleges. The parents give several alternatives to colleges which have a good academic quality, the adequate career guarantee, the qualified lectures, and others.

Nowadays, we are in the globalization era ${ }^{12}$ where it can be identified by the crucial phenomena in the economics. The world economy activities are not limited to the geography borders, languages, cultures, and ideologies, but they are influenced by mutually interdependent factors. ${ }^{13}$ The world seems to have no borders; especially there is the rapid development of information technology. Such circumstances spawn many chances and challenges, ${ }^{14}$ particularly in the efforts of the development of Islamic economics education. ${ }^{15}$

In the midst of swift information and the development of technology in this era, Islamic Economics study program needs to improve Internet-based information facilities in the forms of interactive institutional Website, and

12 Globalization is accepted as one of the fundamental of the processes that characterize the contemporary world, a process leading towards an increasingly strong interdependence between increasingly large parts of the world. S. Parvez Manzoor. 2004. "Book Review 'Islam in the Era of Globalization: Muslim Attitudes Towards Modernity and Identity" by Johan Meuleman (ed.). 2002. London: RoutledgeCurzon, published in Journal of Islamic Studies, Vol. 15, No. 2, May 2004, Oxford: Oxford Centre for Islamic Studies, p. 280.

13 Jan Pronk. 2001. "Globalization: A Developmental Approach", in Jan Nederveen Pieterse (ed.), Global Futures, Shaping Globalization, London: Zed Books, p. 43.

14 Walter Leimgruber. 2004. Between Global and Local, Aldershot (England): Ashgate Publishing Limited, p. 18-19.

15 To understand about the experience and respond of Muslims towards the globalization, see Abdul Rashid Moten. 2005. "Modenization and The Process of Globalization: The Muslim Experience and Responses", in K.S. Nathan and Mohammad Hashim Kamali (eds.), Islam in Southeast Asia: Political, Social and Strategiec Challenges for the 21st Century, Singapura: Institute of Southeast Asian Studies, p. 231-255. 
utilize the social media, such as Twitter, Facebook, Whatsapp, Line, etc. Those aim at facilitating the public, prospective students, and parents to obtain more complete information and detailed information about Islamic Economics study program, without waiting for the brochures.

\section{F. Conclusion}

From the analysis and discussion in the previous chapter, it can be concluded that first, the variable of tuition fee (X1) was 25.41390, and significantly influenced the students' interest in choosing the Islamic Economics study program in Islamic University of Indonesia. Second, the variable of educational facilities (X2) was 24.48315 and significantly influenced the students' interest in choosing the study program. Third, the variable of campus image and popularity of Islamic University of Indonesia was 14.28829, and this factor significantly influenced the students' interest in determining the study program as well. Fourth, the variable of employment opportunities (X4) was 22.21724 and significantly affected the students' interest in choosing the study program. The parents' encouragement and information from the brochure were the most predominant and decisive factors which encouraged the students' interest in choosing Islamic Economics study program with a value of 26.81530. Simultaneously, the factors of the tuition fee, educational facilities, campus image and popularity, employment opportunities, as well as the parents' encouragement and the information of the brochures, brought significant effects towards the students' interest in determining the study program in academic year 2011/2014. Based on R-squared value $\left(\mathrm{R}^{2}\right)$ of $0.989021,98 \%$ students choosing the study program were affected by the factors of the tuition fee (X1), educational facilities (X2), campus image and popularity of the university (X3), employment opportunities (4), parents' encouragement and information from the brochure (X5) together. The other $2 \%$ were not explained in this research.

This research suggests that Islamic Economics study programs need to regard and deliberate the factors of the tuition fee, educational facilities, campus image popularity of the university, employment opportunities, and parents' encouragement as well as information included in the brochures in the decisionmaking of the aim of the study program, and policy establishment, particularly in the marketing to recruit the new students. Islamic Economics study program, 
Faculty of Islamic Studies, Islamic University of Indonesia should improve the online promotion in the form of Internet-based media, such as interactive institutional media, and utilize social media, such as, Twitter, Facebook, Whatsapp, Line, and others. The aims are to facilitate the public, prospective students, and parents to obtain more complete and detailed information about Islamic Economics study program.

\section{DAFTAR PUSTAKA}

Abdul Rashid Moten. 2005. "Modenization and The Process of Globalization: The Muslim Experience and Responses", dalam K.S. Nathan dan Mohammad Hashim Kamali (eds.), Islam in Southeast Asia: Political, Social and Strategiec Challenges for the $21^{\text {st }}$ Century, Singapura: Institute of Southeast Asian Studies

\section{Brosur FIAI UII}

Edy Suandi Hamid, Awan Setia Dewanta dan Yuli andriansyah, 2013. “Analisis

Faktor-Faktor Yang Mempengaruhi Motivasi Calon Mahasiswa Memilih Kuliah Di Universitas Islam Indonesia", DPPM UII.

Erna Ferrinadewi, 2008. Merek Dan Psikologi Konsumen Implikasi Pada Strategi

Pemasaran. Yogyakarta: Graha Ilmu

http:/ / edukasi.kompasiana.com/2013/02/22/telusuri-bakat-minat-dankemampuan-535944.html diakses pda hari tanggal 12/11/2014

http://fis.uii.ac.id/tentang-fiai/sejarah-fiai-uii diakses pada tanggal 12

Desember 2014

http://islamic-economics.uii.ac.id/about-us.html diakses pada tanggal 12 Desember 2014

http:/ / nurkholis77.staff.uii.ac.id/ prospek-pendidikan-ekonomi-islam-dalamkonteks-trend-ekonomi-global/ diakses pada tanggal 4 Desember 2014 http:/ / www.republika.co.id/berita/pendidikan/berita/09/09/24/77793lima-daerah-di-jabar-masukkan-kurikulum-ekonomi-syariah-di-smpsma diakses pada tanggal 5 Desember 2014

http://www.republikapenerbit.com/artikel/detail_info/292, akses12Desember 2014

IndahPiliyanti, "PerspektifMahasiswa(SebuahKajianPemasaranPendidikan)", Tesis, Magister Studi Islam, Universitas Islam Indonesia. 
Jan Pronk. 2001. "Globalization: A Developmental Approach", dalam Jan Nederveen Pieterse (ed.), Global Futures, Shaping Globalization, London: Zed Books.

Nur Kholis, "Potret Politik Ekonomi Islam di Indonesia Era Reformasi", dalam Jurnal MILLAH, Magister Studi Islam UII (accredited), Vol. X, No. 2, Februari 2011

Nur Kholis, "Prospek Pendidikan Ekonomi Islam Dalam Konteks Trend Ekonomi Global", Paper dipresentasikan dalam SIMPONAS Ekonomi Islam ke-4 di Hotel Sahid Raya Yogyakarta, tanggal 8-9 Oktober 2009. OJK, Statistik Perbankan Syariah, Oktober 2014. Publikasi dapat didownload di website OJK (Otoritas Jasa Keuangan), http:/ / www.ojk.go.id/

Parvez Manzoor. 2004. “Book Review 'Islam in the Era of Globalization: Muslim Attitudes Towards Modernity and Identity" oleh Johan Meuleman (ed.). 2002. London: RoutledgeCurzon, dimuat dalam Journal of Islamic Studies, Vol. 15, No. 2, Mei 2004, Oxford: Oxford Centre for Islamic Studies.

Republika, 2 Mei 2007

Riduwan, 2003. Skala Pengukuran Variable-Variable Penelitian, Bandung: Alfabeta

Soeratno dan Lincolin Arsyad, 2008. Metodologi Penelitian Untuk Ekonomi dan Bisnis, Yogyakarta: UPP STIM YKPN

Sulisyanto, 2009. Metode Riset Bisnis, Yogyakarta: Andi Offset Supardi, 2005. Metodologi Penelitian Ekonomi dan Bisnis, Yogyakarta: UII Press Syamsul Hadi, 2006. Metodologi Penelitian Kuantitatifuntuk Akuntansi dan Keuangan, Yogyakarta: Ekonisia

Tatik Suryani, 2008. Perilku Konsumen Implikasi pada Strategi pemasaran, Yogyakata: Graha Ilmu

Walter Leimgruber. 2004. Between Global and Local, Aldershot (England): Ashgate Publishing Limited. 